\title{
Effect of Pre-Sowing Seed Treatment with Plant Growth Regulators on Crop Growth Parameters of Blackgram (Vigna mungo L. Hepper)
}

\author{
N. Gangaraju*, P. Balakrishna, R. Siddaraju and Parashivamurthy \\ Department of Seed Science and Technology, UAS, GKVK, Bengaluru, India \\ *Corresponding author
}

\begin{tabular}{|l|}
\hline K e y w o r d s \\
Growth regulators, \\
$\begin{array}{l}\text { Hydration, } \\
\text { Chemicals, Crop } \\
\text { growth }\end{array}$ \\
\hline Article Info \\
\hline $\begin{array}{l}\text { Accepted: } \\
\text { 04 November } 2019 \\
\text { Available Online: } \\
\text { 10 December } 2019\end{array}$
\end{tabular}

\section{A B S T R A C T}

Study was carried out to assess the comparative efficiency of seven priming techniques on field emergence, speed of emergence and other growth parameters of blackgram cultivars (Rashmi and DU-1). The variety rashmi hydrated with $50 \mathrm{ppm} \mathrm{GA}_{3}$ and surface drying at room temperature (12 hours)was exhibited good results with respect to plant growth viz., field emergence ( 89.33 and $88.67 \%$ ), speed of emergence (21.42 and 20.00), plant height at 30 DAS ( 38.33 and $38.00 \mathrm{~cm}), 60$ DAS (58.47 and 56.40 $\mathrm{cm}$ )and at harvest $(67.00$ and $64.00 \mathrm{~cm})$, number of branches per plant (10.27 and 9.93), plant population at harvest (80.53 and 80.33), plant dry weight at harvest (18.33 and $16.67 \mathrm{~g}$ ) and minimum number of days to maturity (68.33 and 67.00) followed variety by the DU-1Hydrated with 50 ppm $\mathrm{GA}_{3}$ and surface drying at room temperature (12 hours) and lowest growth parameters were recorded in control (seeds without treatment) in both the years (2014 and 2015).

\section{Introduction}

The blackgram (Vigna mungo (L.) Hepper) also known as Vignamungo, black matpe bean, urid, urd, urd bean, udad dal, urad dal, or urad, is a crop that's cultivated in Southern Asia. Blackgram is a major pulse in India that's cultivated all over the country. This crop can be cultivated as a short duration pulse in the early monsoon season and in paddy fallows by utilising residual moisture. One of the major reasons that Indians love this crop is the fact that it improves the fertility of the soil by fixing atmospheric nitrogen content and is resistant to aberrant weather conditions. The seeds comprising 100 gram of seed will contain 3.6 per cent fat, 19 per cent carbohydrates, 3 per cent dietary fiber and 2025 per cent of protein. More importantly, blackgram plays a major role in the typical Indian diet, because it can serve as a supplement to a cereal-based diet and it 
contains vegetable protein. Blackgram also contains iron, folic acid, calcium, magnesium, potassium and vitamin ' $\mathrm{B}$ ' which are necessary for our body. It has two types of fibers: soluble and insoluble. Insoluble fibre helps to prevent constipation and soluble fiber helps in our digestion system. It also helps to reduce cholesterol which ultimately improves cardiovascular health. High amount of magnesium and folate of blackgram support blood circulation. Blackgram has medical properties which help to heal rheumatic pains, stiff shoulder and contracted knees. Compared to many pulse crops a higher per cent of hard seeds and lower per cent of germination were observed in blackgram. Environmental conditions play an important role in development of hard seeds (Donelly, 1970).

Seed invigoration (priming) improves seed performance by any post-harvest treatment that focused on improvement in germiablity, storability and better field performance. Simple method of improving seed germination in the field has been through the use of presowing treatments such as seed priming and Hydro priming is used to improve germinations, increase uniformity of germination and helps to enhance plant establishment. Seeds having priming treatment shows greater germination across a wider range of environmental conditions than unprimed seed and adverse field conditions. The advantage of seed priming is reducing the germination time and improving emergence in field and laboratory conditions. The benefits of seed priming in all crops included faster emergence, uniform stands, drought tolerance and higher plant growth. There are reports that seed priming permits early DNA replication, increase RNA and protein synthesis, enhances embryo growth, repairs deteriorated seed parts and reduces leakage of metabolites. Seed priming is seen as a viable technology to enhance rapid and uniform emergence, high vigor and better yields in some field crops
(Basra et al., 2002; Chiu et al., 2002; Harris et al., 1999; Murungu et al., 2004). Harris et al., 1999, reported seed priming as one of the most important developments to help rapid and uniform germination and emergence of seeds and to increase seed tolerance to adverse climatic conditions.

\section{Materials and Methods}

The field experiments was conducted to study the influence of seed priming with different solutions of chemicals/ active ingredients and plant growth regulators on crop growth of two varieties of blackgram (Rashmi and DU-1) with three replications during Kharif,2014 and 2015at Department of Seed Science and Technology, University of Agricultural Sciences, GKVK, Bangalore-65. Two varieties viz., DU-1 $\left(\mathrm{V}_{1}\right)$, Rashmi $\left(\mathrm{V}_{2}\right)$ and seven treatments with three replicates and each consisted of a control $\left(\mathrm{T}_{1}\right)$, hydration and drying at room temperature below $25^{\circ} \mathrm{C}(12$ hours) $\left(\mathrm{T}_{2}\right)$, iodine (iodine crystals @ $100 \mathrm{mg}$ through calcium carbonate @ $\left.2 \mathrm{~g} \mathrm{~kg}^{-1}\right)\left(\mathrm{T}_{3}\right)$, hydration with $50 \mathrm{ppm} \mathrm{GA}_{3}$ and surface drying at room temperature (12 hours) $\left(\mathrm{T}_{4}\right)$, $\mathrm{KNO}_{3}(0.5 \%)$ hydration and drying at room temperature (12 hours) $\left(\mathrm{T}_{5}\right), \mathrm{KH}_{2} \mathrm{PO}_{4}(0.5 \%)$ hydration and drying at room temperature (12 hours) $\left(\mathrm{T}_{6}\right)$ and Chlorax $5 \mathrm{~g} \mathrm{~kg}^{-1}$ (bleaching powder $)\left(\mathrm{T}_{7}\right)$ with a plot size $2.9 \mathrm{~m} \mathrm{x} 1.8 \mathrm{~m}$ (Gross plot) and $2.4 \mathrm{~m} \mathrm{x} 1.2 \mathrm{~m}$ (Net plot). The experiment was laid out in Randomized Complete Block Design (RCBD) in factorial concept with three replications (FRCBD). Freshly harvested seeds of Black gram varietiesLBG-625 (Rashmi) and DU-1 (hard seed 4-10\%) were obtained from National Seed Project, University of Agricultural Sciences, Raichur and VC farm Mondya. After the harvest of previous crop, land was ploughed once with mould board plough and was brought to fine tilth by repeated harrowing. The residues of previous crop and weeds were removed from experimental area. 
The seeds are invigorated with the above mentioned treatments and used for sowing. The recommended dose of fertilizers (RDF$25 \mathrm{~kg} \mathrm{~N}+50 \mathrm{~kg} \mathrm{P}_{2} \mathrm{O}_{5}+0 \mathrm{~kg} \mathrm{~K}_{2} \mathrm{O} \mathrm{ha}^{-1}$ ) was applied to the plots in the form of urea, diammonium phosphate and muriate of potash. All the fertilizers were applied in a single dose at the time of sowing in furrows opened at $5 \mathrm{~cm}$ away and $5 \mathrm{~cm}$ deep in the soil as basal dose to avoid direct contact of seeds with fertilizers. About 2-3 seeds of blackgram varieties DU-1andRashmi were hand dibbled at $30 \mathrm{~cm}$ and $10 \mathrm{~cm}$ as inter and intra-row spacing, respectively in the earlier opened furrows at 2-3 cm deep.

Five normal and healthy plants were selected randomly from the net plot area of each experimental plot and were tagged with a wax coated label for recording various crop growth components of the present investigation. Details of the various observations recorded are field emergence $(\%)$, speed of emergence $(\%)$, plant height $(\mathrm{cm})$ number of branches per plant, days to 50 per cent flowering, plant population at harvest, plant dry weight at harvest etc. The experimental data collected from field experiments for various crop growth parameters were analysed statistically by adopting appropriate statistical design as described by Sundararaj et al., (1972) and Panse and Sukhatme (1978). The critical difference $(C D)$ values were calculated at five per cent and one per cent probability level wherever ' $F$ ' test was found significant.

\section{Results and Discussion}

Highly significant differences were observed in Rashmi (V2) seeds hydrated with 50 ppm $\mathrm{GA}_{3}$ and surface drying at room temperature (12 hours) ( $\left.\mathrm{T}_{4}\right)$ with respect to field emergence (89.33 and $88.67 \%$ ), speed of emergence (21.42 and 20.00), number of branches per plant (10.27 and 9.93), plant height at 30 DAS $(38.33$ and $38.00 \mathrm{~cm})$, plant height at 60 DAS $(58.47$ and $56.40 \mathrm{~cm})$, plant height at harvest $(67.00$ and $64.00 \mathrm{~cm})$, plant population at harvest (80.53 and 80.33), plant dry weight (18.33 and $16.67 \mathrm{~g})$ and lowest number of days to maturity (68.33 and 67.00) during the both years which is followed byDU-1 (V1) seeds Hydrated with 50 ppm GA3 and surface drying at room temperature (12 hours) $\left(\mathrm{T}_{4}\right)$ viz., field emergence (82.77 and $82.35 \%$ ), speed of emergence (19.92 and 19.00), number of branches per plant $(9.07$ and 9.07), plant height at 30 DAS (36.83 and $36.43 \mathrm{~cm})$, plant height at 60 DAS (52.80 and $51.40 \mathrm{~cm})$, plant height at harvest $(58.07$ and $57.33 \mathrm{~cm})$, plant population at harvest $(79.59$ and 78.00), plant dry weight (17.00 and 15.00 g) and lowest number of days to maturity (72.67 and 70.33), V2T5, V1T5and lowest field emergence (77.00 and $76.00 \%$ ), speed of emergence (15.52 and 14.83), number of branches per plant (5.60 and 5.53), plant height at 30 DAS $(16.43$ and $15.67 \mathrm{~cm})$, plant height at 60 DAS $(37.53$ and $35.90 \mathrm{~cm})$, plant height at harvest $(46.13$ and $43.67 \mathrm{~cm})$, plant population at harvest (74.00 and 71.00), plant dry weight (10.63 and $10.10 \mathrm{~g})$ and highest number of days to maturity (80.33 and 78.67) recorded in V1T1 (control), respectively during both the years (kharif 2014 and kharif 2015).

The superiority $\mathrm{GA}_{3}$ to record higher field performance may be due to its stiv elements effect in the formation of enzymes which are important in the early phases of germination which helps for a fast radicle protrusion and hence and hypocotyl elongation (Riedell et al., 1985 and Maske et al., 1997) (Fig. 1-3 and Table 1 and 2). 
Table.1 Influence of seed priming with hydration, chemicals and growth regulators on growth parameters in black gram (Vigna mungo L. Hepper)

\begin{tabular}{|c|c|c|c|c|c|c|c|c|c|c|}
\hline \multirow[t]{3}{*}{ Treatments } & \multirow{2}{*}{\multicolumn{2}{|c|}{$\begin{array}{c}\text { Field } \\
\text { emergence }(\%)\end{array}$}} & \multirow{2}{*}{\multicolumn{2}{|c|}{$\begin{array}{c}\text { Speed of } \\
\text { emergence }\end{array}$}} & \multicolumn{6}{|c|}{ Plant height $(\mathrm{cm})$} \\
\hline & & & & & \multicolumn{2}{|c|}{30 DAS } & \multicolumn{2}{|c|}{60 DAS } & \multicolumn{2}{|c|}{ At Harvest } \\
\hline & $\begin{array}{c}\text { I } \\
\text { Year }\end{array}$ & II year & $\begin{array}{c}\text { I } \\
\text { Year }\end{array}$ & $\begin{array}{c}\text { II } \\
\text { year }\end{array}$ & $\begin{array}{c}\text { I } \\
\text { Year }\end{array}$ & $\begin{array}{c}\text { II } \\
\text { year }\end{array}$ & $\begin{array}{c}\text { I } \\
\text { Year }\end{array}$ & $\begin{array}{c}\text { II } \\
\text { year }\end{array}$ & I Year & $\begin{array}{c}\text { II } \\
\text { year }\end{array}$ \\
\hline $\mathbf{V}_{1}$ & 80.60 & 79.73 & 17.32 & 16.70 & 26.78 & 26.36 & 45.70 & 44.06 & 52.30 & 50.19 \\
\hline $\mathbf{V}_{2}$ & 82.38 & 81.43 & 18.73 & 17.99 & 30.75 & 30.51 & 49.28 & 47.66 & 56.39 & 54.23 \\
\hline SEm \pm & 0.61 & 0.57 & 0.48 & 0.44 & 0.92 & 0.82 & 1.21 & 1.21 & 1.40 & 1.39 \\
\hline CD $(p=0.05)$ & 1.77 & 1.66 & 1.39 & 1.27 & 2.67 & 2.38 & 3.53 & 3.51 & 4.08 & 4.03 \\
\hline $\mathbf{T}_{1}$ & 77.83 & 76.75 & 16.03 & 15.58 & 19.88 & 19.53 & 39.97 & 38.47 & 48.67 & 45.67 \\
\hline $\mathbf{T}_{2}$ & 82.28 & 81.45 & 18.46 & 17.88 & 30.13 & 29.68 & 48.13 & 46.52 & 54.57 & 52.17 \\
\hline $\mathbf{T}_{\mathbf{3}}$ & 80.14 & 79.50 & 17.38 & 16.83 & 27.13 & 27.13 & 45.80 & 44.15 & 52.63 & 50.83 \\
\hline $\mathbf{T}_{4}$ & 86.05 & 85.51 & 20.67 & 19.50 & 37.78 & 37.02 & 55.63 & 53.90 & 62.53 & 60.67 \\
\hline $\mathbf{T}_{5}$ & 82.65 & 81.80 & 19.00 & 18.38 & 34.55 & 34.13 & 50.77 & 49.13 & 56.50 & 54.73 \\
\hline $\mathbf{T}_{6}$ & 82.03 & 80.82 & 17.66 & 17.08 & 26.60 & 26.33 & 47.57 & 45.95 & 53.87 & 52.03 \\
\hline $\mathbf{T}_{7}$ & 79.45 & 78.25 & 16.98 & 16.17 & 25.38 & 25.10 & 44.57 & 42.91 & 51.67 & 49.40 \\
\hline SEm \pm & 1.14 & 1.07 & 0.90 & 0.82 & 1.72 & 1.53 & 2.27 & 2.26 & 2.62 & 2.59 \\
\hline $\mathrm{CD}(\mathrm{p}=0.05)$ & 3.32 & 3.11 & 2.61 & 2.38 & 5.00 & 4.46 & 6.60 & 6.57 & 7.63 & 7.54 \\
\hline $\mathbf{V}_{1} \mathbf{T}_{1}$ & 77.00 & 76.00 & 15.52 & 14.83 & 16.43 & 15.67 & 37.53 & 35.90 & 46.13 & 43.67 \\
\hline $\mathrm{V}_{2} \mathbf{T}_{1}$ & 78.67 & 77.50 & 16.55 & 16.33 & 23.33 & 23.40 & 42.40 & 41.03 & 51.20 & 47.67 \\
\hline $\mathbf{V}_{1} \mathbf{T}_{2}$ & 82.00 & 81.24 & 17.92 & 17.50 & 30.10 & 29.58 & 48.07 & 46.43 & 53.60 & 51.33 \\
\hline $\mathbf{V}_{2} \mathbf{T}_{2}$ & 82.57 & 81.67 & 19.00 & 18.25 & 30.17 & 29.77 & 48.20 & 46.60 & 55.53 & 53.00 \\
\hline $\mathbf{V}_{1} \mathbf{T}_{3}$ & 79.80 & 79.00 & 16.52 & 16.00 & 26.83 & 26.60 & 44.53 & 42.77 & 50.93 & 48.67 \\
\hline $\mathbf{V}_{2} \mathbf{T}_{3}$ & 80.47 & 80.00 & 18.25 & 17.67 & 27.43 & 27.67 & 47.07 & 45.53 & 54.33 & 53.00 \\
\hline $\mathbf{V}_{1} \mathbf{T}_{4}$ & 82.77 & 82.35 & 19.92 & 19.00 & 36.83 & 36.43 & 52.80 & 51.40 & 58.07 & 57.33 \\
\hline $\mathbf{V}_{2} \mathbf{T}_{4}$ & 89.33 & 88.67 & 21.42 & 20.00 & 38.33 & 38.00 & 58.47 & 56.40 & 67.00 & 64.00 \\
\hline $\mathbf{V}_{1} \mathbf{T}_{5}$ & 82.33 & 81.42 & 18.42 & 17.83 & 34.33 & 33.92 & 48.80 & 47.07 & 55.53 & 53.33 \\
\hline $\mathrm{V}_{2} \mathbf{T}_{5}$ & 82.96 & 82.16 & 19.58 & 18.92 & 34.77 & 34.33 & 52.73 & 51.20 & 57.47 & 56.13 \\
\hline$V_{1} T_{6}$ & 81.40 & 80.63 & 17.25 & 16.42 & 24.37 & 24.27 & 47.07 & 45.20 & 52.33 & 50.00 \\
\hline $\mathrm{V}_{2} \mathrm{~T}_{6}$ & 82.67 & 81.00 & 18.07 & 17.73 & 28.83 & 28.40 & 48.07 & 46.70 & 55.40 & 54.06 \\
\hline $\mathbf{V}_{1} \mathbf{T}_{7}$ & 78.90 & 77.50 & 15.72 & 15.33 & 18.37 & 18.20 & 41.13 & 39.65 & 49.53 & 47.00 \\
\hline $\mathbf{V}_{2} \mathbf{T}_{7}$ & 80.00 & 79.00 & 18.25 & 17.00 & 32.40 & 32.00 & 48.00 & 46.17 & 53.80 & 51.80 \\
\hline SEm \pm & 1.61 & 1.51 & 1.27 & 1.16 & 2.43 & 2.17 & 3.21 & 3.20 & 3.71 & 3.67 \\
\hline $\mathrm{CD}(\mathrm{p}=0.05)$ & 4.69 & 4.40 & 3.69 & 3.37 & 7.07 & 6.31 & 9.33 & 9.30 & 10.79 & 10.66 \\
\hline CV (\%) & 3.43 & 3.25 & 12.18 & 11.16 & 14.67 & 13.22 & 11.71 & 12.07 & 11.82 & 12.16 \\
\hline
\end{tabular}

Verities

$\mathbf{V}_{1}-$ DU-1,

$\mathbf{V}_{\mathbf{2}}-$ Rashmi
Treatments

$\mathbf{T}_{1}$-Control

$\mathbf{T}_{2}$-Hydration and drying at room temperature below $25^{\circ} \mathrm{C}$ (12 hours)

$\mathbf{T}_{\mathbf{3}}$-Iodine (Iodine crystals @ $100 \mathrm{mg}$ through calcium carbonate @ $2 \mathrm{~g} \mathrm{~kg}^{-1}$ )

$\mathbf{T}_{\mathbf{4}}$-Hydration with $50 \mathrm{ppm} \mathrm{GA3}$ and surface drying at room temperature (12 hours)

$\mathbf{T}_{5}-\mathrm{KNO}_{3}(0.5 \%)$ hydration and drying at room temperature (12 hours)

$\mathbf{T}_{\mathbf{6}}-\mathrm{KH}_{2} \mathrm{PO}_{4}(0.5 \%)$ hydration and drying at room temperature (12 hours)

$\mathbf{T}_{7}$-Chlorax $5 \mathrm{~g} \mathrm{~kg}^{-1}$ (bleaching powder) 
Table.2 Influence of seed priming with hydration, chemicals and growth regulators on growth parameters in black gram (Vigna mungo L. Hepper)

\begin{tabular}{|c|c|c|c|c|c|c|c|c|}
\hline \multirow[t]{2}{*}{ Treatments } & \multicolumn{2}{|c|}{$\begin{array}{c}\text { Number of } \\
\text { branches per plant }\end{array}$} & \multicolumn{2}{|c|}{$\begin{array}{c}\text { Plant population } \\
\text { at harvest }\end{array}$} & \multicolumn{2}{|c|}{$\begin{array}{l}\text { Number of days } \\
\text { to maturity }\end{array}$} & \multicolumn{2}{|c|}{$\begin{array}{c}\text { Plant dry weight } \\
\text { at harvest (g) }\end{array}$} \\
\hline & I Year & II year & I Year & II year & I Year & II year & I Year & II year \\
\hline $\mathbf{V}_{1}$ & 7.30 & 7.10 & 77.54 & 74.86 & 76.57 & 75.38 & 13.47 & 12.48 \\
\hline $\mathbf{V}_{2}$ & 8.40 & 8.25 & 78.47 & 76.25 & 74.40 & 73.25 & 14.25 & 13.35 \\
\hline SEm \pm & 0.23 & 0.29 & 0.29 & 0.41 & 0.74 & 0.72 & 0.17 & 0.30 \\
\hline $\mathrm{CD}(\mathrm{p}=\mathbf{0 . 0 5})$ & 0.66 & 0.84 & 0.86 & 1.20 & 2.16 & 2.10 & 0.50 & 0.86 \\
\hline $\mathbf{T}_{1}$ & 6.57 & 6.37 & 75.83 & 72.83 & 79.50 & 77.50 & 11.73 & 10.64 \\
\hline $\mathbf{T}_{2}$ & 8.23 & 8.17 & 78.18 & 73.91 & 73.83 & 74.00 & 15.08 & 13.71 \\
\hline $\mathbf{T}_{\mathbf{3}}$ & 6.93 & 6.89 & 77.96 & 75.48 & 77.42 & 75.92 & 12.20 & 11.98 \\
\hline $\mathbf{T}_{4}$ & 9.66 & 9.50 & 80.05 & 79.17 & 70.50 & 68.66 & 17.67 & 15.83 \\
\hline $\mathbf{T}_{5}$ & 8.50 & 8.17 & 78.89 & 76.96 & 74.00 & 72.83 & 15.50 & 14.42 \\
\hline $\mathbf{T}_{6}$ & 7.93 & 7.63 & 78.16 & 75.80 & 75.83 & 74.46 & 13.04 & 11.96 \\
\hline $\mathbf{T}_{7}$ & 7.12 & 6.98 & 76.99 & 74.73 & 77.33 & 76.83 & 11.88 & 11.84 \\
\hline SEm \pm & 0.42 & 0.54 & 0.55 & 0.78 & 1.39 & 1.35 & 0.32 & 0.55 \\
\hline $\operatorname{CD}(p=0.05)$ & 1.23 & 1.56 & 1.60 & 2.25 & 4.05 & 3.93 & 0.93 & 1.61 \\
\hline $\mathbf{V}_{1} \mathbf{T}_{1}$ & 5.60 & 5.53 & 74.00 & 71.00 & 80.33 & 78.67 & 10.63 & 10.10 \\
\hline $\mathbf{V}_{2} \mathbf{T}_{1}$ & 7.53 & 7.20 & 77.67 & 74.67 & 78.67 & 76.33 & 12.83 & 11.17 \\
\hline $\mathbf{V}_{1} \mathbf{T}_{2}$ & 8.07 & 7.93 & 78.49 & 73.63 & 75.00 & 74.33 & 14.83 & 13.50 \\
\hline$V_{2} T_{2}$ & 8.40 & 8.40 & 77.86 & 74.19 & 72.67 & 73.67 & 15.33 & 13.92 \\
\hline$V_{1} T_{3}$ & 6.53 & 6.53 & 77.40 & 75.10 & 79.00 & 77.33 & 12.55 & 11.67 \\
\hline $\mathbf{V}_{\mathbf{2}} \mathbf{T}_{\mathbf{3}}$ & 7.32 & 7.25 & 78.53 & 75.86 & 75.83 & 74.50 & 11.87 & 12.29 \\
\hline $\mathbf{V}_{1} \mathbf{T}_{4}$ & 9.07 & 9.07 & 79.59 & 78.00 & 72.67 & 70.33 & 17.00 & 15.00 \\
\hline $\mathbf{V}_{2} \mathbf{T}_{4}$ & 10.27 & 9.93 & 80.53 & 80.33 & 68.33 & 67.00 & 18.33 & 16.67 \\
\hline $\mathbf{V}_{1} \mathbf{T}_{5}$ & 8.07 & 7.67 & 78.59 & 76.40 & 74.33 & 73.00 & 14.67 & 14.00 \\
\hline $\mathbf{V}_{2} \mathbf{T}_{5}$ & 8.93 & 8.67 & 79.19 & 77.53 & 73.67 & 72.67 & 16.33 & 14.84 \\
\hline $\mathbf{V}_{1} \mathbf{T}_{6}$ & 7.33 & 6.80 & 77.93 & 75.40 & 76.67 & 76.00 & 13.05 & 11.72 \\
\hline$V_{2} T_{6}$ & 8.53 & 8.47 & 78.39 & 76.19 & 75.00 & 72.92 & 13.03 & 12.20 \\
\hline $\mathbf{V}_{1} \mathbf{T}_{7}$ & 6.40 & 6.13 & 76.84 & 74.47 & 78.00 & 78.00 & 11.66 & 11.33 \\
\hline $\mathrm{V}_{2} \mathbf{T}_{7}$ & 7.83 & 7.83 & 77.13 & 75.00 & 76.67 & 75.67 & 12.08 & 12.34 \\
\hline SEm \pm & 0.60 & 0.76 & 0.78 & 1.10 & 1.97 & 1.91 & 0.45 & 0.78 \\
\hline$C D(p=0.05)$ & 1.74 & 2.21 & 2.27 & 3.19 & NS & NS & 1.31 & 2.28 \\
\hline $\mathrm{CV}(\%)$ & 13.22 & 14.18 & 6.53 & 7.15 & 6.34 & 6.28 & 5.64 & 10.51 \\
\hline
\end{tabular}

Verities

$\mathbf{V}_{1}-\mathrm{DU}-1$,

$\mathbf{V}_{\mathbf{2}}-$ Rashmi
Treatments

$\mathbf{T}_{1}$-Control

$\mathbf{T}_{\mathbf{2}}$-Hydration and drying at room temperature below $25^{\circ} \mathrm{C}$ (12 hours)

$\mathbf{T}_{3}$-Iodine (Iodine crystals @ $100 \mathrm{mg}$ through calcium carbonate @ $2 \mathrm{~g} \mathrm{~kg}^{-1}$ )

$\mathbf{T}_{\mathbf{4}}$-Hydration with $50 \mathrm{ppm} \mathrm{GA3}$ and surface drying at room temperature (12 hours)

$\mathbf{T}_{\mathbf{5}}-\mathrm{KNO}_{3}(0.5 \%)$ hydration and drying at room temperature (12 hours)

$\mathbf{T}_{\mathbf{6}}-\mathrm{KH}_{2} \mathrm{PO}_{4}(0.5 \%)$ hydration and drying at room temperature (12 hours)

$\mathbf{T}_{7}$-Chlorax $5 \mathrm{~g} \mathrm{~kg}^{-1}$ (bleaching powder) 
Fig.1 Effect of pre-sowing seed treatments on field emergence (\%) and speed of emergence of blackgram (Vigna mungo (L.) Hepper)
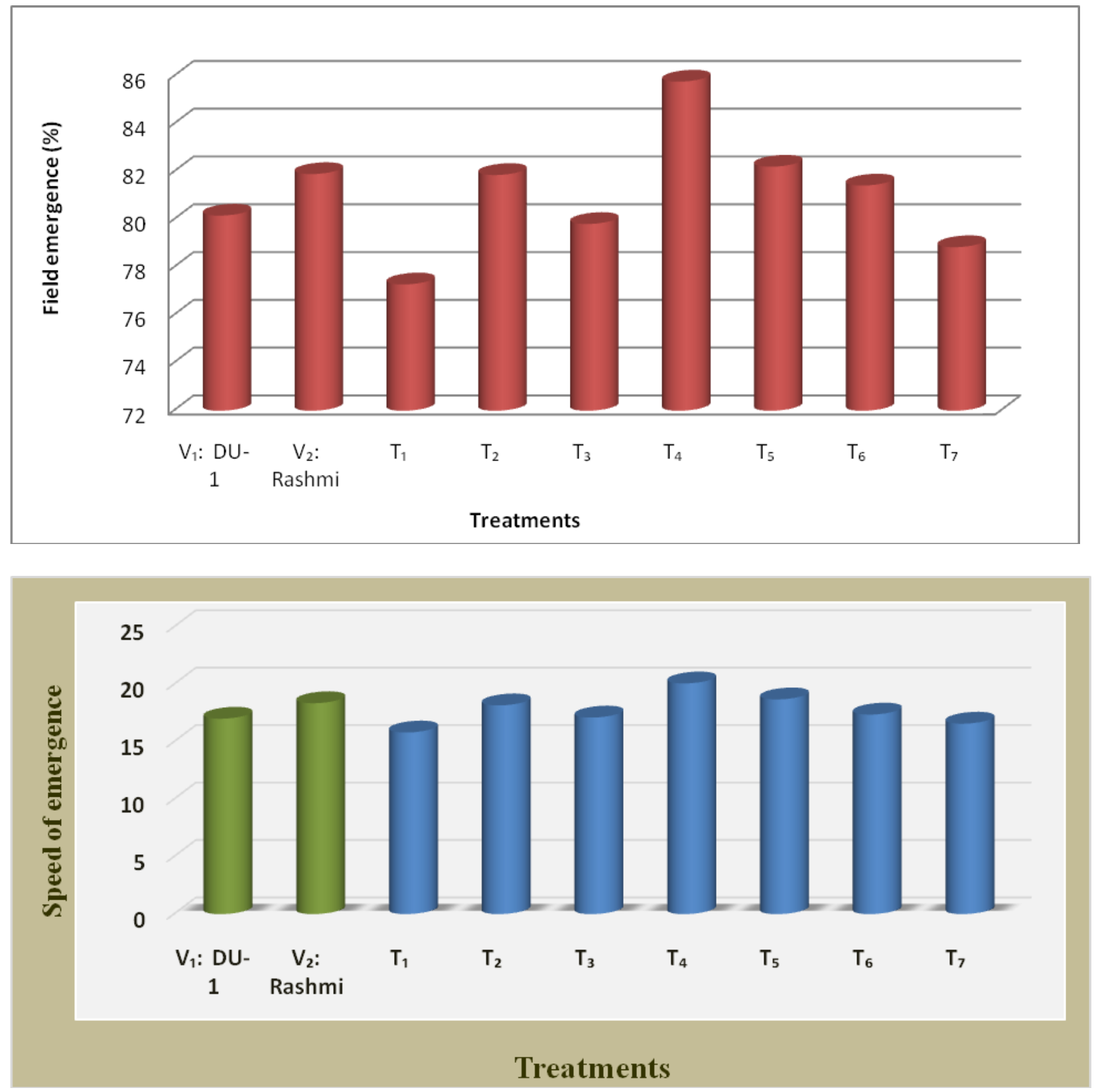

\section{Treatments}

$\mathbf{T}_{1}$-Control

$\mathbf{T}_{\mathbf{2}}$-Hydration and drying at room temperature below $25^{\circ} \mathrm{C}$ (12 hours)

$\mathbf{T}_{\mathbf{3}}$-Iodine (Iodine crystals @ $100 \mathrm{mg}$ through calcium carbonate @ $2 \mathrm{~g} \mathrm{~kg}^{-1}$ )

$\mathbf{T}_{4}$-Hydration with 50 ppm $\mathrm{GA}_{3}$ and surface drying at RT (12 hours)

$\mathbf{T}_{5}-\mathrm{KNO}_{3}(0.5 \%)$ hydration and drying at RT (12 hours)

$\mathbf{T}_{\mathbf{6}}-\mathrm{KH}_{2} \mathrm{PO}_{4}(0.5 \%)$ and drying at RT (12 hours)

$\mathbf{T}_{7}$-Chlorax $5 \mathrm{~g} \mathrm{~kg}^{-1}$ 
Fig.2 Effect of pre-sowing seed treatments on plant height $(\mathrm{cm})$ of Blackgram [Vigna mungo (L.) Hepper]
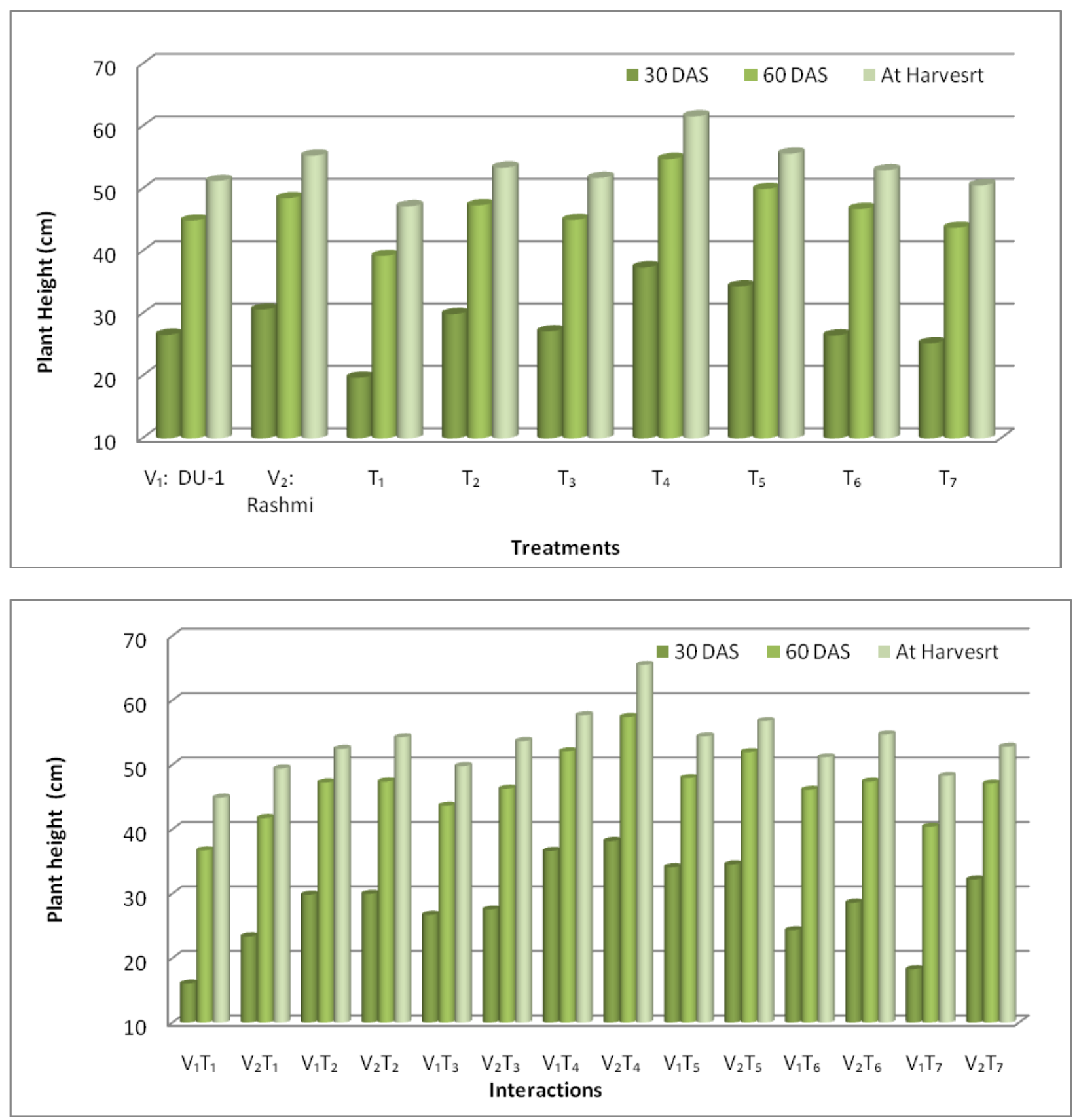

\section{Treatments}

$\mathbf{T}_{1}$-Control

$\mathbf{T}_{\mathbf{2}}$-Hydration and drying at room temperature below $25^{\circ} \mathrm{C}$ ( 12 hours)

$\mathbf{T}_{3}$-Iodine (Iodine crystals @ $100 \mathrm{mg}$ through calcium carbonate @ $2 \mathrm{~g} \mathrm{~kg}^{-1}$ )

$\mathbf{T}_{\mathbf{4}}$-Hydration with $50 \mathrm{ppm} \mathrm{GA}$ and surface drying at RT (12 hours)

$\mathbf{T}_{\mathbf{5}}-\mathrm{KNO}_{3}(0.5 \%)$ hydration and drying at RT (12 hours)

$\mathbf{T}_{6}-\mathrm{KH}_{2} \mathrm{PO}_{4}(0.5 \%)$ and drying at RT (12 hours)

$\mathbf{T}_{7}$-Chlorax $5 \mathrm{~g} \mathrm{~kg}^{-1}$ 
Superiority of $\mathrm{GA}_{3}$ to record higher speed of germination may be due to its stimulation effect in the formation of enzymes which are important in the early phases of germination which helps for a fast radicle protrusion and hence and hypocotyl elongation (Haba et al., 1985; Khafagi et al., 1986; Kumar and Neelakandan, 1992; Maske et al., 1997), stem elongation and flower development (Yamaguchi and Kamiya, 2000). The effects of $\mathrm{GA}_{3}$ are the transformation of genetically dwarf plants into tall ones by greatly increasing stem elongations had reported that $\mathrm{GA}_{3}$ application results in stem elongation. The elongation of the internodes of Phaseolus vulgaris was chiefly the results of increases in plant height as reported by Kato (1955), Brian (1959) and Katsumi et al., (1965). GA 3 affects a remarkable increase in height of shoots in blackgram and green gram (Patel and Saxena, 1994). Significant increase in vegetative growth and plant height as a result treatment of $\mathrm{GA}_{3}$ was reported by Venkataramaiah and Swami (1981). The highest plant stand in variety Rashmi and seeds treated with $50 \mathrm{ppm}$ could be due to invigoration of seeds by using $\mathrm{GA}_{3}$ showed strong stem development, resistance against varied environmental conditions and diseases. This highest plant stand in variety Rashmi might be due to well response of this variety to $\mathrm{GA}_{3}$. The results are agreed with findings of manzurul and Shahidulhaque (2002) in mungbean. The increased plant dry weight is might be due to $\mathrm{GA}_{3}$ play essential roles in the breakdown of reserve starch in germinating seeds (Jacobsen and Chandler, 1987).

Pre-sowing seed treatment is helpful in better seed germination, increased speed of emergence, reducing the risk of poor stand establishment under a wide range of environmental conditions and good crop growth. Our findings revealed that blackgram seeds Hydrated with 50 ppm GA3 and surface drying at room temperature (12 hours) (T4) is best and useful technique for enhancing seedling emergence rate and percentage of germination. These effects can improve seedling establishment and field performance of this important food legume.

\section{References}

Basra SMA, Zia MN, Mehmood, T., Afzal, I. and Khaliq, A. 2002. Comparison of different invigoration techniques in wheat seeds. Pak. J. Arid Agric., 5:11-16.

BRIAN, P. W. 1958, Role of gibberellin-like hormones in regulation of plant growth and flowering. Nature Land, 181:1122.

Chiu, K. Y., Chen, C. L. and Sung, J. M. 2002, Effect of priming temperature on storability of primed sh-2 sweet corn seed. Crop Sci., 42: 1996-2003.

Donelly, E. D., 1970, Persistence of hard seed in vicia lines derived from interspecific hybridization. Crop Sci., 10:661-662.

Haba, P., De-La, Roldan, J. M. and Jimenez, F., 1985, Antagonistic effect of gibberellic acid and boron on protein and carbohydrate metabolism of soybean germinating seeds. J. Plant Nutrition, 8:1061-1073.

Harris, D., Joshi, A., Khan, P. A., Gothkar, P., Sodhi, P. S., 1999, Onfarm seed priming in semi-arid agriculture development and evaluation in maize, rice and chickpea in India using participatory methods. Exp. Agric., 35: 15-29.

Jacobsen, J. V., and Chandler, P. M. 1987, Gibberellin and abscisic acid in germinating cereals. In PJ Davies, ed. Plant hormones and their role in plant growth and development. Norwell, MA: Martinus-Nijhoff, 164-193.

Kato, Y., 1955, Responses of plant cells to gibberellin. Bot. Gaz., 16-117 
Katsumi, M., Purves, W. K., Phinny, B. O. and KATO, J., 1965, The role of cotyledons in gibberlins and auxin induced elongation of the cucumber hypocotyl. Physiolplant., 18:550-556.

Khafagi, O. A., Khalaf, S. M. and ELLawendy, W. I., 1986, Effect of $\mathrm{GA}_{3}$ and CCC on germination and growth of soybean, common bean, cowpea and pigeon pea plants grown under different levels of salinity. Ann. Agric. Sci., 24:1965-1982.

Kumar, K. G. A. and NEELAKANDAN, N., 1992, Effect of growth regulators on seedling vigour in soybean (Glycine $\max (\mathrm{L}$.$) \quad Merr.). Legume Res.,$ 15:181-182.

Manzurulhoque and Shahidulhaque, M. D., 2002, Effects of gibberellic acid $\left(\mathrm{GA}_{3}\right)$ on physiological contributing characters of mungbean (Vigna radiata L.). Pak. J. Biological Sci., 5(4): 401-403

Maske, V. G., Dotale, R. D., Sorte, P. N., Tale, B. D. and Chore, C. N., 1997, Germination, root and shoot studies in soybean as influenced by $\mathrm{GA}_{3}$ and NAA. J. Soils Crop, 7: 147-149.

Murungu, F. S., Chiduza, C., Nyamugafata, P., Clark, L. J., Whalley, W. R. and Finch-Savage, W. E., 2004, Effects of 'on-farm seed priming' on consecutive daily sowing occasions on the emergence and growth of maize in semi-arid Zimbabwe. Field Crops Res., 89:49-57.

Panse, V. G. and Sukhatme, P. V., 1978, Statistical Methods for Agricultural Workers. Published by Indian Council of Agricultural Research.

PAtel, I. and Saxena, O. P. 1994, Growth and yields of blackgram as influenced by seed soaking treatments and plant growth regulators. Legume Res., 17: 65-69.

Riedell, W. E., Khoo, U. and Inglett, G. E., 1985, Effects of bioregulators on soybean leaf structure and chlorophyll retention in plant growth regulation, Lake Alfred, Florida. Principles and Procedures Statistics, pp.172-177.

Sundararaj, N., Nagaraju, S., Venkata RAMU, M. N. and Jagannath, M. R., 1972, Design and Analysis of Experiments. University of Agricultural Sciences, Bangalore, 148-155.

Venkataramaiah and Swami, 1981, Reported that foliar application of $\mathrm{GA}_{3}$ to one month old seedlings of. Pterocarpus santalinus L. A Review of Literature on Gibberlic Acid. Chapter-2.

Yamaguchi, S. and Kamiya, Y., 2000, Gibberellin biosynthesis: its regulation by endogenous and environmental signals. Plant and Cell Physiology, 4: 251-257.

\section{How to cite this article:}

Gangaraju, N., P. Balakrishna, R. Siddaraju and Parashivamurthy. 2019. Effect of Pre-Sowing Seed Treatment with Plant Growth Regulators on Crop Growth Parameters of Blackgram (Vigna mungo L. Hepper). Int.J.Curr.Microbiol.App.Sci. 8(12): 199-207. doi: https://doi.org/10.20546/ijcmas.2019.812.029 